\title{
TrkB Gene Transfer Protects Retinal Ganglion Cells from Axotomy-Induced Death In Vivo
}

\author{
Li Cheng, ${ }^{1}$ Przemyslaw Sapieha, ${ }^{1}$ Pavla Kittlerová, ${ }^{2}$ William W. Hauswirth, ${ }^{3}$ and Adriana Di Polo ${ }^{1}$ \\ ${ }^{1}$ Department of Pathology and Cell Biology, Université de Montréal, Montreal, Quebec H3T 1J4, Canada, ${ }^{2}$ Montreal \\ General Hospital Research Institute, McGill University, Montreal, Quebec H3G 1A4, Canada, and ${ }^{3}$ Department of \\ Ophthalmology and Powell Gene Therapy Center, University of Florida, Gainesville, FL 32610-0284
}

Injury-induced downregulation of neurotrophin receptors may limit the response of neurons to trophic factors, compromising their ability to survive. We tested this hypothesis in a model of CNS injury: retinal ganglion cell (RGC) death after transection of the adult rat optic nerve. TrkB mRNA rapidly decreased in axotomized RGCs to $\sim 50 \%$ of the level in intact retinas. TrkB gene transfer into RGCs combined with exogenous BDNF administration markedly increased neuronal survival: $76 \%$ of RGCs remained alive at 2 weeks after axotomy, a time when

Trauma or disease often leads to neuronal cell death and loss of functional connections. Strategies to promote the recovery of the injured CNS have been limited by the death of large numbers of neurons soon after damage. Neurotrophins play important roles in the survival response of adult neurons after injury (Lewin and Barde, 1996; Huang and Reichardt, 2001; Sofroniew et al., 2001). In the visual system, BDNF has been identified as a potent survival factor for axotomized retinal ganglion cells (RGCs) (Mey and Thanos, 1993; Mansour-Robaey et al., 1994; Aguayo et al., 1996; Peinado-Ramon et al., 1996; Klöcker et al., 1998; Chen and Weber, 2001), which are known to express the BDNF receptor TrkB (Jelsma et al., 1993; Pérez and Caminos, 1995; Rickman and Brecha, 1995). For example, a single intravitreal injection of BDNF supports the survival of virtually all RGCs up to 1 week after axotomy (Mansour-Robaey et al., 1994). In contrast, nearly one-half of axotomized RGCs die in untreated retinas.

Long-term studies on the survival of RGCs have demonstrated that the effect of exogenous BDNF is temporary: it delays, but does not prevent, the onset of RGC death (Mansour-Robaey et al., 1994; Clarke et al., 1998; Di Polo et al., 1998). Administration of BDNF by repeated intravitreal injections or osmotic minipumps failed to extend the time course of RGC protection (Mansour-Robaey et al., 1994; Clarke et al., 1998). Moreover, delivery of BDNF by adenovirus-infected retinal glial cells provided a sustained source of neurotrophin but resulted in transient

\footnotetext{
Received Dec. 10, 2001; revised Feb. 20, 2002; accepted Feb. 26, 2002.

This work was supported by grants from the Canadian Institutes of Health Research and the Glaucoma Research Foundation (A.D.P.), National Institutes of Health Grant EY11123, and Research to Prevent Blindness, Inc. (W.W.H). A.D.P. is a scholar of Fonds de la Recherche en Santé du Québec. We thank Drs. A. Aguayo and G. Bray for discussions in the early stages of this study; Drs. D. Kaplan, P. Barker, and T. Kennedy for comments on this manuscript; and M. Attiwell, C. Zeindler, and V. Chiodo for technical assistance.

Correspondence should be addressed to Dr. Adriana Di Polo, Department of Pathology and Cell Biology, Université de Montréal 2900, Boulevard EdouardMontpetit, Pavillon Principal, Room N-535, Montreal, Quebec H3T 1J4, Canada. E-mail: dipoloa@patho.umontreal.ca.

Copyright (ㄷ) 2002 Society for Neuroscience $0270-6474 / 02 / 223977-10 \$ 15.00 / 0$
}

$>90 \%$ of these neurons are lost without treatment. Activation of mitogen-activated protein kinase, but not phosphatidylinositol-3 kinase, was required for TrkB-induced survival. These data provide proof-of-principle that enhancing the capacity of injured neurons to respond to trophic factors can be an effective neuroprotective strategy in the adult CNS.

Key words: retinal ganglion cells; axotomy; gene transfer; TrkB; MAP kinase; cell survival

RGC rescue (Di Polo et al., 1998). The mechanism underlying this loss of trophic support is poorly understood.

A possible explanation for the short-lived neuroprotective effect of BDNF is that the intrinsic capacity of RGCs to respond to this neurotrophin is compromised by injury (Di Polo et al., 1998). To test this hypothesis we addressed the following questions. First, are there axotomy-induced changes in TrkB gene expression in adult RGCs? Because TrkB mediates the response of RGCs to BDNF, we examined whether axotomy leads to detectable changes in TrkB mRNA synthesis. Second, does in vivo upregulation of TrkB receptor expression extend RGC survival? To address this issue, we used recombinant adeno-associated virus (AAV) to deliver the TrkB gene into adult RGCs. In contrast to adenovirus, AAV evokes minimal immune response in the host (Xiao et al., 1996, 1997) and mediates long-term transgene expression that can persist in the retina for at least 1 year after vector administration (Dudus et al., 1999; Guy et al., 1999).

Finally, what signaling pathways mediate survival triggered by TrkB activation in adult RGCs in vivo? During binding to Trk receptors, neurotrophins stimulate multiple signaling pathways, including the $\mathrm{MEK} / \mathrm{mitogen}$ activated protein kinase (MAPK) and the phosphatidylinositol-3 kinase (PI-3K)/Akt pathways (Segal et al., 1996; Klesse and Parada, 1999; Kaplan and Miller, 2000). Studies on the participation of these pathways in neurotrophin-induced survival have been limited to neurons in culture (Xia et al., 1995; Bartlett et al., 1997; Dudek et al., 1997; Crowder and Freeman, 1998; Meyer-Franke et al., 1998; Skaper et al., 1998; Bonni et al., 1999; Dolcet et al., 1999; Klesse et al., 1999; Atwal et al., 2000; Orike et al., 2001) or at early developmental stages in vivo (Anderson and Tolkovsky, 1999; Hetman et al., 1999; Hee Han and Holtzman, 2000). Thus, the role of neurotrophin-activated signaling pathways in the survival of adult CNS neurons in vivo remains undefined.

In this study, we demonstrate that TrkB mRNA levels are reduced in RGCs soon after transection of the optic nerve and before the onset of cell death. TrkB gene delivery to RGCs, in 
combination with exogenous BDNF, markedly extends the survival of these neurons after axonal injury. Our results indicate that activation of the MEK/MAPK pathway, but not the PI-3K/ Akt pathway, mediates TrkB-induced RGC rescue.

\section{MATERIALS AND METHODS}

Quantitative in situ hybridization. Antisense oligonucleotide probes corresponding to bp 2324-2368 of the tyrosine kinase domain of full-length rat TrkB (44-mer) and bp 1899-1944 of the tyrosine kinase domain of full-length rat TrkC (48-mer) were labeled with ${ }^{35} \mathrm{~S}$-dATP (NEN, Markham, Ontario, Canada) using terminal deoxynucleotidyl transferase (Invitrogen, Burlington, Ontario, Canada). These probes correspond to nonhomologous regions of TrkB or TrkC cDNAs, respectively. In situ hybridization was performed on radial cryosections $(7-10 \mu \mathrm{m})$ prepared from fresh retinal tissue. Hybridization was performed essentially as described (Dangerlind et al., 1992). Briefly, sections were hybridized overnight at $42^{\circ} \mathrm{C}$ with $10^{7} \mathrm{cpm}$ of radiolabeled probe in $1 \mathrm{ml}$ of hybridization solution in saline sodium citrate (SSC) containing formamide $(50 \%)$, dextran sulfate $(100 \mathrm{gm} / \mathrm{l})$, sarcosyl $(1 \%)$, phosphate buffer $(20$ $\mathrm{mm}, \mathrm{pH} 7.0)$, salmon sperm DNA (500 gm/1), and dithiothreitol (200 $\mathrm{mm}$ ). After hybridization, slides were washed in SSC and then dehydrated in ascending concentrations of ethanol. Slides were dipped in Kodak NTB2 autoradiographic emulsion (Kodak, Rochester, NY), dried, and stored in a light-proof box at $4^{\circ} \mathrm{C}$ for $1-2$ months. Sections were then developed for $5 \mathrm{~min}$ in Kodak D-19 at $20^{\circ} \mathrm{C}$, rinsed, and fixed for $5 \mathrm{~min}$ in Kodak fix. Tissue sections were counterstained with $0.25 \%$ thionin (Sigma, Oakville, Ontario, Canada) and mounted in Entellan (VWR, Mississauga, Ontario, Canada). Negative controls included sections hybridized with sense probes, sections treated with RNase A (50 $\mu \mathrm{g} / \mathrm{ml}$; Boehringer Mannheim, Laval, Quebec, Canada) at $37^{\circ} \mathrm{C}$ for 30 min, and slides incubated with 100 -fold excess of unlabeled TrkB or TrkC receptor probe. An image analysis system (Image1, Universal Imaging Corp., West Chester, PA) was used to determine the number of autoradiographic silver grains per neuron. The average number of grains per RGC was counted for experimental and control retinas, mounted on the same slide, and normalized to the levels found in the corresponding contralateral intact retina. Data and statistical analysis were performed using SigmaStat (Jandel, Corte Madera, CA).

Preparation of recombinant $A A V$ vectors. A construct containing a c-myc epitope-tagged form of full-length rat TrkB, provided by Dr. P. Barker (McGill University), was used to generate AAV vectors. The TrkB gene was inserted downstream of the cytomegalovirus (CMV) promoter in plasmid pTR-UF5 (Zolotukhin et al., 1996) containing the AAV terminal repeat sequences and a simian virus 40 polyadenylation sequence. An AAV control vector containing the green fluorescent protein (GFP) gene, but lacking the TrkB gene, was generated in an identical manner. Packaging of AAV vectors was performed as described previously (Hauswirth et al., 2000). Briefly, low-passage human 293 cells were cotransfected with pTR-UF5-TrkB and the helper plasmid pDG (Grimm et al., 1998) that contains both the AAV genes (rep and cap) and the adenovirus genes required for AAV propagation. After the cells were harvested, the virus was extracted by freezing and thawing the cells, and the supernatant was then clarified by low-speed centrifugation. Crude cell lysates containing AAV were loaded onto Iodixanol (Nycomed Pharma, Oslo, Norway) density step gradients for purification. The fraction containing AAV was further purified by heparin affinity chromatography (Sigma). Purified AAV was concentrated and desalted by centrifugation through Biomax 100K filters (Millipore, Mississauga, Ontario, Canada) according to the manufacturer's instructions. Viral titers, determined by quantitative-competitive PCR and infectious center assay (Hauswirth et al., 2000), were in the order of $5 \times 10^{12}$ physical particles per milliliter. No helper virus was used in this preparation to avoid contamination of AAV stocks with adenovirus. Wild-type AAV contamination was below the levels of detection (1 part in $10^{7}$ ).

Surgical procedures. Animal procedures were performed in accordance with the guidelines for the use of experimental animals (Olfert et al., 1993). All surgeries were performed in female adult Sprague Dawley rats (180-200 gm) under general anesthesia (7\% chloral hydrate; $0.42 \mathrm{mg} / \mathrm{gm}$ of body weight, i.p.). Viral vectors ( $5 \mu$ l total volume) were injected into the vitreous chamber in the dorsal hemisphere of the left eye using a 10 $\mu$ l Hamilton syringe fitted with a 32 gauge needle. The tip of the needle was inserted through the sclera and retina into the vitreous space using a posterior approach. This route of administration avoided injury to other structures of the eye, such as the iris or lens, which have been shown to promote RGC survival (Mansour-Robaey et al., 1994; Leon et al., 2000). The right eye was left untouched and served as internal contralateral control for each animal. For RGC survival experiments, cells were retrogradely labeled with $2 \%$ FluoroGold (Fluorochrome, Englewood, NJ) in $0.9 \% \mathrm{NaCl}$ containing $10 \%$ dimethyl sulfoxide (DMSO) by application of the tracer to both superior colliculi. Seven days later, the left optic nerve was transected $0.5-1 \mathrm{~mm}$ from the optic nerve head. In some experimental groups, the following agents were injected intravitreally in the superior hemisphere in a total volume of 5 $\mu \mathrm{l}$ at the time of axotomy: the MEK inhibitor PD98059, 100-200 $\mu \mathrm{M}$ in PBS containing 20\% DMSO (New England Biolabs, Mississauga, Ontario, Canada); the PI-3 kinase inhibitor LY294002, 100-800 $\mu \mathrm{M}$ in PBS with $20 \%$ DMSO (Sigma); BDNF protein, $1 \mu \mathrm{g} / \mu \mathrm{l}$ in PBS containing $1 \%$ bovine serum albumin (provided by Regeneron Pharmaceuticals, Tarrytown, NY), or vehicle (PBS or PBS containing 20\% DMSO). Rats were killed by intracardial perfusion with $4 \%$ paraformaldehyde and both the left (optic nerve lesion) and right (intact control) retinas were dissected, fixed for an additional $30 \mathrm{~min}$, and flat-mounted vitreal side up on a glass slide for examination of the ganglion cell layer.

Immunocytochemistry. Rats were perfused intracardially with $4 \%$ paraformaldehyde in $0.1 \mathrm{M}$ phosphate buffer $(\mathrm{PB}), \mathrm{pH} 7.4$, and the eyes were immediately enucleated. The anterior part of the eye and the lens were removed, and the remaining eye cup was immersed in the same fixative for $2 \mathrm{hr}$ at $4^{\circ} \mathrm{C}$. Eye cups were equilibrated in graded sucrose solutions $(10-30 \%$ in $\mathrm{PB})$ for several hours at $4^{\circ} \mathrm{C}$, embedded in O.C.T. compound (Tissue-Tek, Miles Laboratories, Elkhart, IN) and frozen in a 2-methylbutane/liquid nitrogen bath. Radial cryosections $(6-12 \mu \mathrm{m})$ were collected onto gelatin-coated slides and processed. Sections were incubated in $10 \%$ normal goat serum (NGS), $0.2 \%$ Triton X-100 (Sigma) in PBS for $30 \mathrm{~min}$ at room temperature to block nonspecific binding. Each primary antibody was added in $2 \%$ NGS, $0.2 \%$ Triton X-100 and incubated overnight at $4^{\circ} \mathrm{C}$. Sections were then incubated with the appropriate secondary antibody for $1 \mathrm{hr}$ at room temperature, washed in PBS, and mounted using an anti-fade reagent (SlowFade, Molecular Probes, Eugene, OR). Alternatively, whole retinas were dissected and processed for immunostaining under conditions similar to those used for radial cryosections with the exception that retinas were permeabilized in $2 \%$ Triton X-100 and $0.5 \%$ DMSO in PBS for $3-6 \mathrm{~d}$ at $4^{\circ} \mathrm{C}$, and all incubations were done with free-floating tissue. Whole-mount retinas and retinal sections were visualized with fluorescent microscopy (Zeiss Axiovert). Antibodies were as follows: anti-c-myc antibody $(5 \mu \mathrm{g} / \mathrm{ml}$; Oncogene, Cedarlane Laboratories, Hornby, Ontario, Canada), antiglial fibrillary acidic protein (GFAP) $(5 \mu \mathrm{g} / \mathrm{ml}$; Chemicon International, Temecula, CA), anti-vimentin (5 $\mu \mathrm{g} / \mu \mathrm{l}$; Chemicon), FITC-conjugated isolectin B4 (20 $\mu \mathrm{g} / \mathrm{ml}$; Sigma), and ED-1 (10 $\mu \mathrm{g} / \mathrm{ml}$; Chemicon), fluorophore-conjugated goat anti-mouse IgG (red, $4 \mu \mathrm{g} / \mathrm{ml}$; Alexa 594, Molecular Probes).

Neuronal quantification. For quantification of AAV-mediated TrkB expression in neurons in the ganglion cell layer, histological sections of the retina were produced along the dorsal-ventral plane of the eye, and serial sections that passed through the optic nerve head, used as reference, were analyzed. The entire number of labeled cells per section was then counted using a fluorescent microscope. Six to eight serial sections per eye were typically counted per experimental animal. For neuronal survival studies, the ganglion cell layer was examined in whole-mount retinas with fluorescence microscopy, and FluoroGold-labeled neurons were counted in 12 standard retinal areas as described (Villegas-Perez et al., 1993). Data analysis and statistics were performed using the SigmaStat program (Jandel) by a one-way ANOVA or a Student's $t$ test (paired groups).

Western blot analysis. Fresh retinas were rapidly dissected and homogenized with an electric pestle (Kontes, Vineland, NJ) in ice-cold lysis buffer: $20 \mathrm{~mm}$ Tris, $\mathrm{pH}$ 8.0, $135 \mathrm{~mm} \mathrm{NaCl}, 1 \% \mathrm{NP}-40,0.1 \%$ SDS, and $10 \%$ glycerol supplemented with protease inhibitors (1 mM phenylmethyl sulfonyl fluoride, $10 \mu \mathrm{g} / \mathrm{ml}$ aprotinin, $1 \mu \mathrm{g} / \mathrm{ml}$ leupeptin, and $0.5 \mathrm{~mm}$ sodium orthovanadate). After incubation for $30 \mathrm{~min}$ on ice, homogenates were centrifuged at $10,000 \mathrm{rpm}$ for $10 \mathrm{~min}$, and the supernatants were removed and resedimented for an additional $10 \mathrm{~min}$ to yield solubilized extracts. Alternatively, 200-300 $\mu \mathrm{g}$ of protein was immunoprecipitated with anti-pan Trk 203, provided by D. Kaplan (McGill University), as described (Stephens et al., 1994). Retinal extracts (75-100 $\mu \mathrm{g}$ ) or immunoprecipitated samples were resolved on $8 \%$ SDS polyacrylamide gels and transferred to nitrocellulose filters (Bio-Rad Life Science, Mississauga, Ontario, Canada). To block nonspecific binding, filters were placed in $10 \mathrm{~mm}$ Tris, $\mathrm{pH} 8.0,150 \mathrm{~mm} \mathrm{NaCl}, 0.2 \%$ Tween 20 (TBST), and 
$5 \%$ dry skim milk for $1 \mathrm{hr}$ at room temperature. Blots were then incubated for $16-18 \mathrm{hr}$ at $4^{\circ} \mathrm{C}$ with each of the following primary antibodies: anti-phospho-p44/42 MAP kinase $(0.8 \mu \mathrm{g} / \mathrm{ml}$, New England Biolabs), anti-p44/42 MAP kinase (20-80 ng/ml, New England Biolabs), anti-phospho-Akt $(0.6 \mu \mathrm{g} / \mathrm{ml}$, New England Biolabs), anti-Akt $(0.1 \mu \mathrm{g} /$ $\mathrm{ml}$, New England Biolabs), or anti-phosphotyrosine (4G10, $1 \mu \mathrm{g} / \mathrm{ml}$; Upstate Biotechnology, Waltham, MA). Membranes were washed in TBST and incubated in anti-rabbit or anti-mouse peroxidase-linked secondary antibodies $(0.5 \mu \mathrm{g} / \mathrm{ml}$; Amersham Biosciences, Baie d'Urfé, Quebec, Canada) for $1 \mathrm{hr}$ at room temperature. Blots were developed with a chemoluminescence reagent (ECL, Amersham Biosciences) and exposed to X-OMAT (Kodak) imaging film.

\section{RESULTS}

\section{TrkB mRNA levels are downregulated in axotomized RGCs}

We investigated the changes in TrkB gene expression in axotomized RGCs by quantitative in situ hybridization. An oligonucleotide probe specific for the catalytic domain of full-length rat TrkB was used in these experiments. Probe hybridization to intact retinas produced a robust positive signal, visualized by dark-field microscopy at low magnification, in cells of the ganglion cell layer and inner nuclear layer (Fig. $1 A$ ). One week after axotomy, the hybridization signal was markedly reduced only in the ganglion cell layer (Fig. 1B). No signal was detected in retinal sections hybridized with a sense probe or treated with RNase A (data not shown). The number of autoradiographic silver grains was quantified in single RGC cell bodies and visualized with thionin staining in intact and injured retinas using bright-field microscopy (Fig. 1C,D). Experimental and control retinas were mounted on the same slide and processed under identical conditions. As early as $3 \mathrm{~d}$ after axotomy, TrkB mRNA in RGCs was decreased by $\sim 40 \%$ (11.9 \pm 4 grains per cell; mean $\pm \mathrm{SD}$ ) relative to unoperated contralateral retinas $(100 \%=20.3 \pm 2$ grains per cell $)$ (Fig. 1E). The decline in TrkB gene expression was detected before the onset of RGC death that typically starts at $5 \mathrm{~d}$ after axotomy (Berkelaar et al., 1994). The average number of grains per RGC continued to decrease during the first week after injury and remained low, between $45 \%$ ( $8.9 \pm 4$ grains per cell) and $60 \%$ (12 \pm 2 grains per cell) of the contralateral control levels, thereafter. These results indicate that the reduction of grain density in RGCs cannot be attributed to cell death caused by axotomy but to reduced TrkB mRNA levels in surviving RGCs. Amacrine cells, which are known to express TrkB (Cellerino and Kohler, 1997), populate the inner nuclear layer and the ganglion cell layer (Perry, 1981) but do not project axons to the optic nerve. Because amacrine cells are typically smaller than RGCs, cellular profiles of $<70 \mu \mathrm{m}^{2}$ were identified as amacrine cells as described (McKerracher et al., 1993). In contrast to RGCs, TrkB mRNA levels in amacrine cells remained unchanged after axotomy (Fig. $1 F$ ), confirming our ability to distinguish between these two cellular populations.

\section{AAV-mediated TrkB is predominantly expressed by adult RGCs}

For gene transfer experiments, a recombinant AAV vector containing a c-myc-tagged full-length rat TrkB gene under control of the CMV promoter was produced. Intravitreal injection of AAV.TrkB resulted in TrkB protein expression exclusively in the ganglion cell layer, as detected by immunostaining with an antibody against c-myc (Fig. $2 A$ ). No other retinal layer showed positive c-myc immunostaining. Robust c-myc labeling was localized on neuronal cell bodies and RGC axons in the fiber layer. Intact contralateral retinas or retinas infected with a control virus did not show positive c-myc staining. Because displaced amacrine cells account for $\sim 40 \%$ of the total number of neurons in the ganglion cell layer of the rat retina (Perry, 1981), we sought to identify the cellular targets of AAV infection in this system. For this purpose, we performed colocalization studies in retinas from eyes that received a single intravitreal injection of AAV.TrkB followed by retrograde labeling of RGCs with the tracer FluoroGold applied to both superior colliculi. Double-labeling experiments demonstrated that the majority of RGCs, visualized with FluoroGold (Fig. $2 B$ ), also produced virally mediated TrkB (Fig. $2 C)$. AAV.TrkB transgene expression reached a plateau at 3-4 weeks after administration of the vector and persisted for at least 10 weeks in the intact retina. The mechanism underlying the delay in the onset of gene product expression in vivo, characteristic of AAV vectors (Malik et al., 2000), remains undefined but may be related to the need to convert single-stranded viral DNA to a double-stranded form before gene transcription (Ferrari et al., 1996).

To determine the efficacy of adult RGC transduction by AAV, we quantified the number of c-myc- and FluoroGold-labeled cells in retinal sections at 4 weeks after vector administration. An average of $68 \%$ of FluoroGold-labeled neurons were also c-myc positive, indicating that RGCs were successfully transduced by the AAV.TrkB vector (Fig. 2D). A small population of c-mycpositive cells $(\sim 8 \%)$ was not labeled with FluoroGold and may represent amacrine cells transduced by AAV or RGCs that did not incorporate the retrograde tracer. Immunostaining with an antibody against GFAP or vimentin, in combination with c-myc, did not show colocalization (data not shown), indicating that glial cells in the retina were not infected by AAV. Taken together, these results indicate that RGCs are the primary target for AAV transduction in the adult inner retina.

\section{TrkB upregulation protects RGCs from axotomy-induced cell death}

The effect of AAV.TrkB on RGC survival in vivo was tested using the experimental protocol outlined in Figure $3 A$. Four weeks after intraocular injection of viral vectors, RGCs were retrogradely labeled and subsequently axotomized. Retinas were examined histologically at 7, 14, 21, and $28 \mathrm{~d}$ after optic nerve transection to determine the density of surviving RGCs (Fig. 3B, Table 1). A single intraocular injection of AAV.TrkB resulted in a moderate, but significant, neuroprotective effect at 1 and 2 weeks after axotomy. For example, AAV.TrkB supported the survival of $27 \%$ of RGCs compared with $9.6 \%$ neuronal survival induced by the control virus at 2 weeks after injury. We then examined whether AAV.TrkB treatment combined with a single intravitreal injection of BDNF protein at the time of axotomy could potentiate RGC survival. This approach yielded markedly higher RGC densities at all times examined (Fig. 3B). At 2 weeks after axotomy, AAV.TrkB with BDNF protected $76 \%$ of RGCs, whereas independent administration of BDNF or AAV.TrkB promoted 38 or $27 \%$ neuronal survival, respectively. This effect, although reduced, was still significant at 3 and 4 weeks after axotomy, resulting in higher neuronal densities and better preservation of cellular integrity than with AAV.TrkB (Fig. $4 A, B$ ) or BDNF alone.

To determine whether TrkB gene transfer was involved in this effect, we examined the correlation between neuronal survival and transgene product expression. At 3 weeks after axotomy, virtually all surviving RGCs $(\sim 96 \%)$ also expressed AAVmediated TrkB (Fig. 4C,D). Positive c-myc staining was clearly 

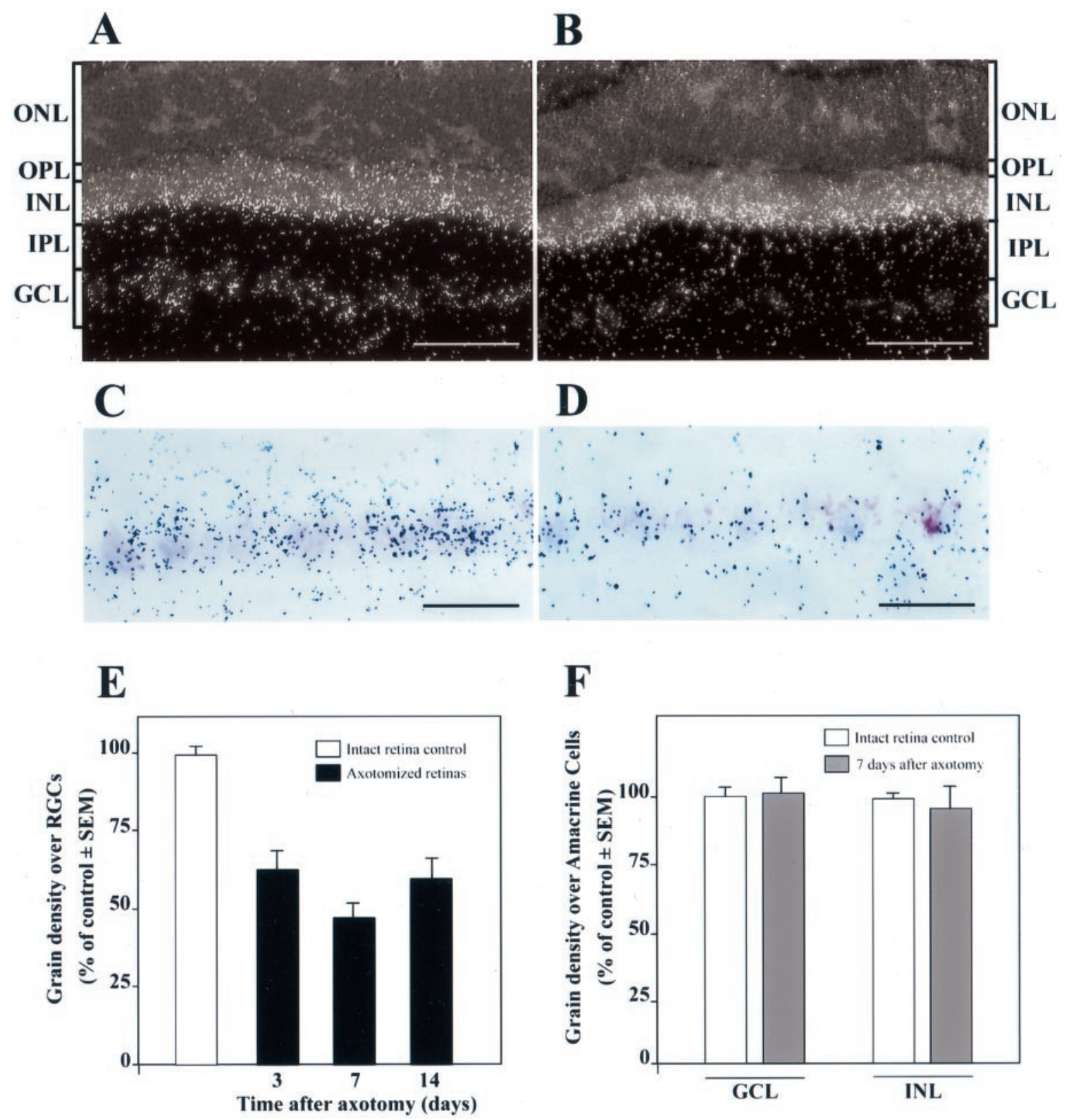

Figure 1. TrkB mRNA in intact and injured adult rat retinas. Dark-field micrographs after in situ hybridization using a probe that selectively recognizes the tyrosine kinase domain of full-length rat TrkB are shown for intact $(A)$ and axotomized $(B)$ retinas. TrkB mRNA is predominantly expressed in RGCs and displaced amacrine cells in the ganglion cell layer $(G C L)$, as well as in amacrine cells in the inner nuclear layer (INL). After transection of the optic nerve, TrkB mRNA was reduced only in cells of the GCL $(B)$ (1 week after axotomy). Bright-field micrographs of the RGC layer of intact ( $C$ ) and axotomized retinas $(D)$ (1 week after axotomy) from sections counterstained with toluidine blue were used to quantify the number of grains corresponding to the TrkB probe on neuronal cell bodies. Size criteria were used to distinguish RGCs $\left(>70 \mu \mathrm{m}^{2}\right)$ from displaced amacrine cells $(<70$ $\mu \mathrm{m}^{2}$ ). The non-cross-reactivity of the TrkB probe with TrkC, another neurotrophin receptor found in neurons of the ganglion cell layer, was established by using a $100 \mathrm{M}$ excess of either unlabeled TrkC probe or TrkB probe in the hybridization solution. Unlike the excess of TrkB probe, the TrkC probe did not compete out the TrkB hybridization signal (data not shown). E, Time course of TrkB mRNA downregulation in axotomized RGCs was assessed by quantitative in situ hybridization. The average number of grains per RGC was normalized to the level found in contralateral intact retinas (100\%). TrkB mRNA was reduced in RGCs, but not in amacrine cells $(F)$, to $\sim 50-60 \%$ of the levels in intact control retinas $(n=4-6$ per time point; $p<0.001)$. This decrease in TrkB gene expression was detected as early as $3 \mathrm{~d}$ after axotomy before the onset of RGC death. ONL, Outer nuclear layer; $O P L$, outer plexiform layer; $I N L$, inner nuclear layer; $I P L$, inner plexiform layer; $G C L$, ganglion cell layer. Scale bars: $A, B, 50 \mu \mathrm{m} ; C, D, 25 \mu \mathrm{m}$.

visualized on the surface of RGCs that remained alive, suggesting that TrkB delivered by AAV was effectively transported to the membrane. Together, these results strongly suggest that upregulation of receptor expression supports RGC survival in this injury model. Microglia and macrophages that may have incorporated FluoroGold after phagocytosis of dying RGCs were excluded from our analysis of neuronal survival on the basis of their morphology, which can be easily identified in retinal whole mounts (Fig. 4B). In addition, the identity of these cells was confirmed by immunostaining with antibodies against the microglia and macrophage markers isolectin-B4 and ED-1 (data not shown). 

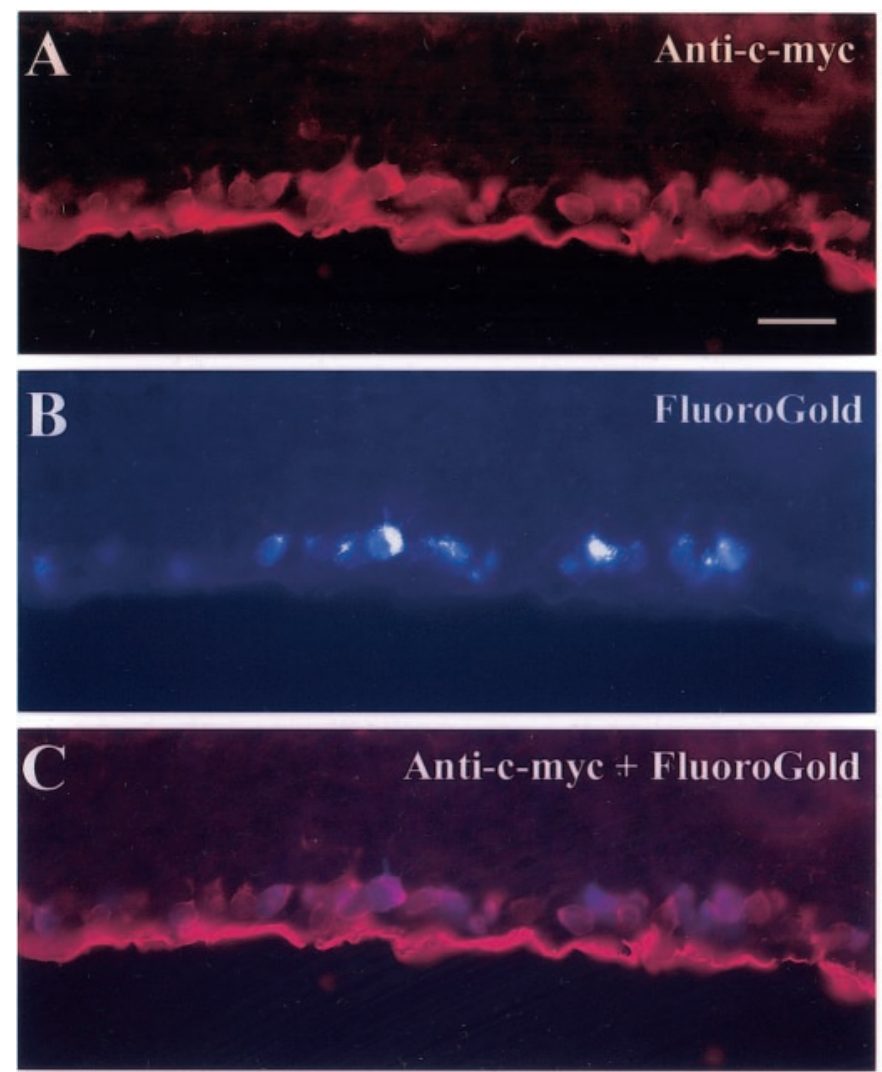

D

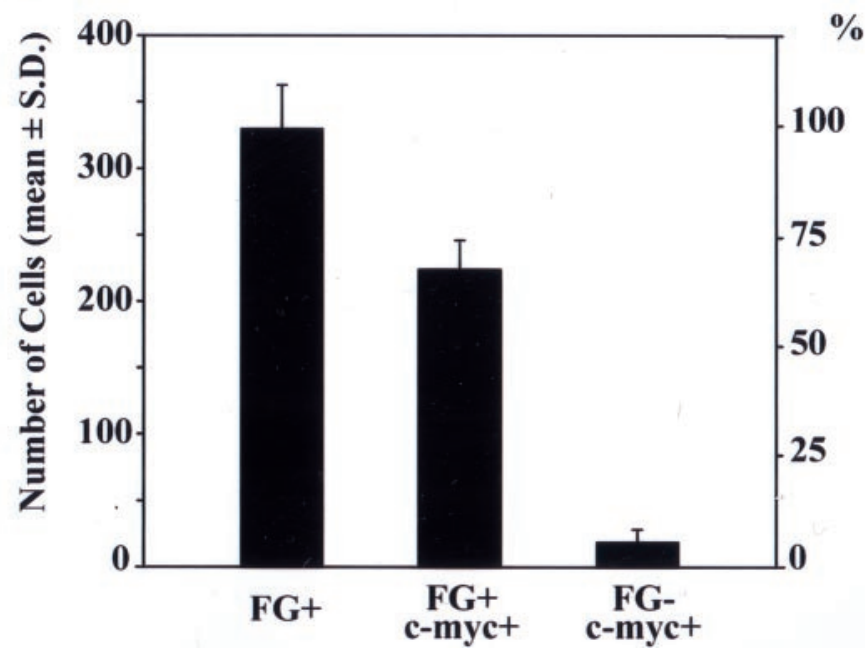

Figure 2. AAV-mediated TrkB gene product expression in adult RGCs. Fluorescent microscopy images of retinal sections after intraocular injection of AAV.TrkB. A, Virally mediated TrkB was visualized using an anti-c-myc antibody that stained neuronal cell bodies in the ganglion cell layer as well as RGC axons in the fiber layer. $B, \mathrm{RGCs}$ were identified by retrograde labeling during application of the tracer FluoroGold to the superior colliculus, the main target for these neurons in the rat brain. $C$, Superimposition of the images in $A$ and $B$ demonstrates that the vast majority of RGCs expressed the AAV.TrkB gene product. Adjacent sections labeled with FluoroGold alone did not show bleed-through between filters (data not shown). Scale bar, $10 \mu \mathrm{m}$. $D$, Quantification of the number of cells in the ganglion cell layer expressing AAV-mediated TrkB protein at 4 weeks after intraocular injection of the vector. The total number of RGCs per retinal section was assessed by their FluoroGold label $(F G+)$ and compared with the number of cells costained with an anti-c-myc antibody $(c-m y c+)$, which recognized AAV-mediated TrkB, and FluoroGold. An average of $68 \%$ of the total number of RGCs per

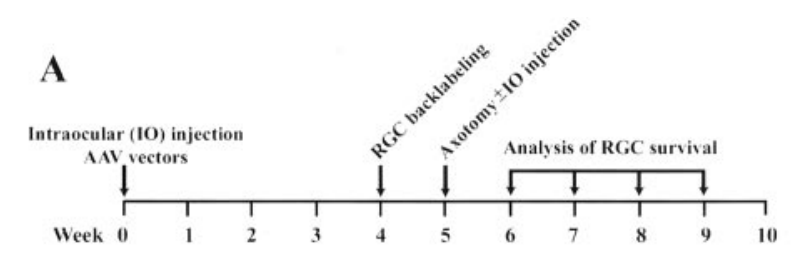

B

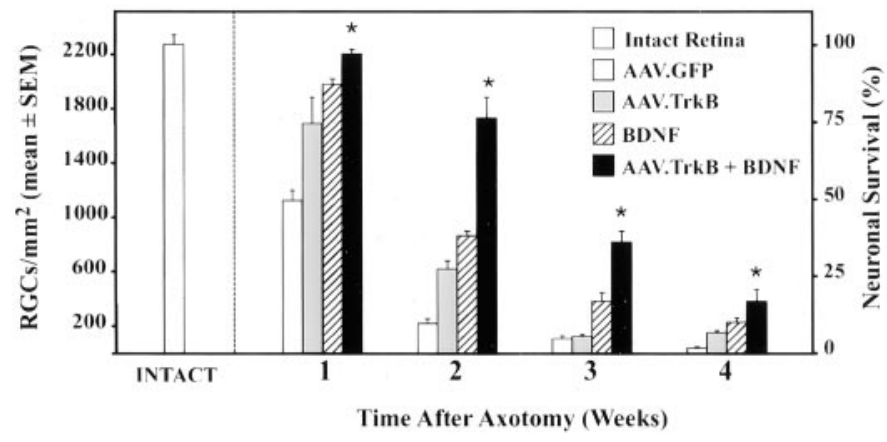

Figure 3. Effect of TrkB gene transfer on the protection of axotomized RGCs in vivo. A, Outline of the experimental protocol used to test the effect of AAV.TrkB on RGC survival. Four weeks after intraocular injection of viral vectors, the time required for transgene expression to reach a plateau in the adult rat retina, RGCs were retrogradely labeled with FluoroGold and subsequently axotomized. RGC survival was assessed by quantification of fluorescent neurons in whole-mounted retinas. $B$, Quantitative analysis of RGC survival after intravitreal injection of AAV.TrkB (gray bars), BDNF recombinant protein (hatched bars), AAV.TrkB and BDNF protein (solid bars), and AAV.GFP (open bars) at $7,14,21$, and $28 \mathrm{~d}$ after optic nerve transection ( $n=3-15$ rats per group) (Table 1). The density of RGCs in intact unoperated retinas is shown as reference (stippled bar). The neuroprotective effect of AAV.TrkB was greatly enhanced when combined with a single intravitreal injection of BDNF at the time of axotomy. The synergistic effect of AAV.TrkB and BDNF was significantly larger than independent administration of AAV.TrkB or BDNF protein at all times examined $(p<0.001)$.

\section{Retinal MAPK and Akt are activated after TrkB gene transfer}

To identify the signaling pathways involved in AAV.TrkBinduced neuroprotection, we examined whether TrkB gene transfer had an effect on receptor tyrosine phosphorylation, the initial step for transduction of survival signals. Western blot analysis of immunoprecipitated Trk proteins using an antibody against phosphotyrosine demonstrated TrkB activation at 5 weeks (Fig. 5A) and 10 weeks (data not shown) after intravitreal injection of AAV.TrkB. We then compared AAV-induced TrkB tyrosine phosphorylation with that produced by a single intravitreal injection of BDNF recombinant protein. Robust TrkB tyrosine phosphorylation was detected at $48 \mathrm{hr}$ after administration of BDNF (Fig. $5 A$ ) but not at $10 \mathrm{~d}$ after injection of the neurotrophin (data not shown). These data indicate that AAV.TrkB induced moderate but sustained levels of TrkB activation, whereas BDNF protein provoked robust but transient stimulation of this receptor. Injection of PBS or AAV.GFP did not have any effect on TrkB activation (Fig. $5 A$ ).

retinal section expressed the AAV.TrkB transgene $(n=4 ; p<0.001)$ Few c-myc-positive cells $(\sim 8 \%)$ were not labeled with FluoroGold $(F G-)$. These results indicate that RGCs are the primary cellular target for AAV infection in the inner retina. 


\begin{tabular}{|c|c|c|c|c|c|}
\hline \multirow[b]{2}{*}{ Treatment } & & \multicolumn{4}{|c|}{$\mathrm{RGCs} / \mathrm{mm}^{2} \pm \mathrm{SEM}(\%$ of intact contralateral retinas); $n$} \\
\hline & & \multicolumn{4}{|c|}{ Time after axotomy } \\
\hline Viral vector & Agent injected ${ }^{a}$ & 1 week & 2 weeks & 3 weeks & 4 weeks \\
\hline AAV.GFP & & $\begin{array}{c}1131 \pm 53 \\
(50 \%) ; n=3 \\
1692 \pm 190\end{array}$ & $\begin{array}{c}220 \pm 32 \\
(10 \%) ; n=5 \\
620 \pm 60\end{array}$ & $\begin{array}{c}104 \pm 24 \\
(5 \%) ; n=3 \\
124 \pm 10\end{array}$ & $\begin{array}{c}38 \pm 2 \\
(2 \%) ; n=3 \\
152 \pm 10\end{array}$ \\
\hline AAV.TrkB & & $\begin{array}{c}(75 \%) ; n=4 \\
2203 \pm 24\end{array}$ & $\begin{array}{c}(27 \%) ; n=7 \\
1732 \pm 150\end{array}$ & $\begin{array}{c}(6 \%) ; n=8 \\
817 \pm 79\end{array}$ & $\begin{array}{c}(7 \%) ; n=3 \\
378 \pm 88\end{array}$ \\
\hline AAV.TrkB & BDNF protein & $\begin{array}{c}(97 \%) ; n=4 \\
1981 \pm 42\end{array}$ & $\begin{array}{c}(76 \%) ; n=4 \\
866 \pm 32\end{array}$ & $\begin{array}{c}(36 \%) ; n=5 \\
381 \pm 62\end{array}$ & $\begin{array}{c}(17 \%) ; n=5 \\
226 \pm 26\end{array}$ \\
\hline & BDNF protein & $(87 \%) ; n=4$ & $\begin{array}{c}(38 \%) ; n=5 \\
594 \pm 81\end{array}$ & $(17 \%) ; n=4$ & $(10 \%) ; n=4$ \\
\hline AAV.TrkB & LY294002 & & $\begin{array}{c}(26 \%) ; n=6 \\
227 \pm 15\end{array}$ & & \\
\hline AAV.TrkB & PD98059 & & $\begin{array}{c}(10 \%) ; n=5 \\
210 \pm 17\end{array}$ & & \\
\hline AAV.GFP & LY294002 & & $\begin{array}{c}(9 \%) ; n=3 \\
234 \pm 13\end{array}$ & & \\
\hline AAV.GFP & PD98059 & & $(10 \%) ; n=3$ & & \\
\hline
\end{tabular}

Contralateral intact retinas: $2271 \pm 64 \mathrm{RGCs} / \mathrm{mm}^{2}(100 \%) ; n=15$.

antravitreal injection performed at the time of axotomy.

Figure 4. Correlation of RGC survival and AAVmediated TrkB expression in injured retinas. Flatmounted retinas show FluoroGold-labeled RGCs after intravitreal administration of AAV.TrkB and BDNF protein $(A)$ or only AAV.TrkB $(B)$ at 3 weeks after axotomy. Microglia that may have incorporated FluoroGold after phagocytosis of dying RGCs were distinguished by their morphology (arrowheads) and excluded from our quantitative analyses. The identity of these cells was also confirmed by immunostaining using microglia and macrophage markers (data not shown). Scale bar, $20 \mu \mathrm{m}$. $C$, Fluorescent microscopy images of retinal sections after AAV.TrkB and BDNF administration show colocalization of anti-c-myc labeling, which was used to visualize AAV-mediated TrkB, and FluoroGold, which was used to identify surviving RGCs, at 3 weeks after axotomy. Scale bar, 10 $\mu \mathrm{m}$. $D$, Quantification of the number of cells in the ganglion cell layer costained with FluoroGold $(F G+)$ and anti-c-myc $(c-m y c+)$ indicate that an average of $\sim 96 \%$ of surviving RGCs express AAVmediated TrkB protein. The population of RGCs labeled with both markers $(F G+, c-m y c+)$ is not significantly different from the total number of surviving RGCs $(F G+)(n=4$ per experimental group; $p=0.769)$. These data suggest that TrkB upregulation increases RGC responsiveness to

$\mathbf{A}$

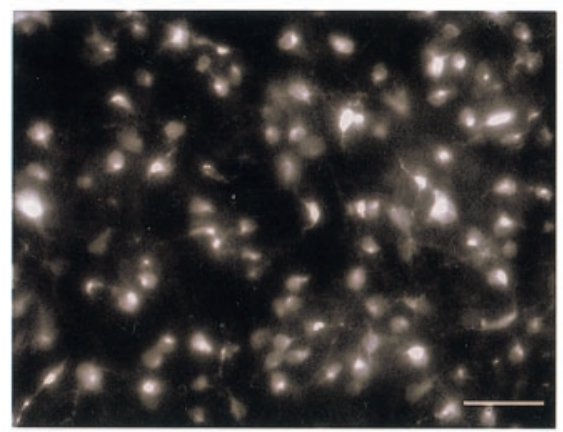

C
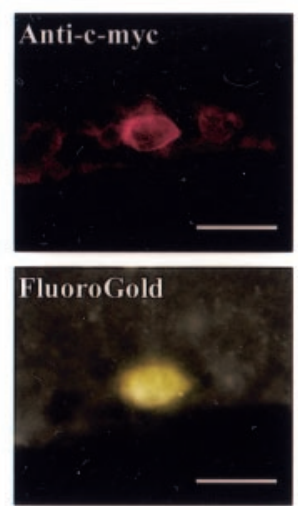

B

AAV.TrkB

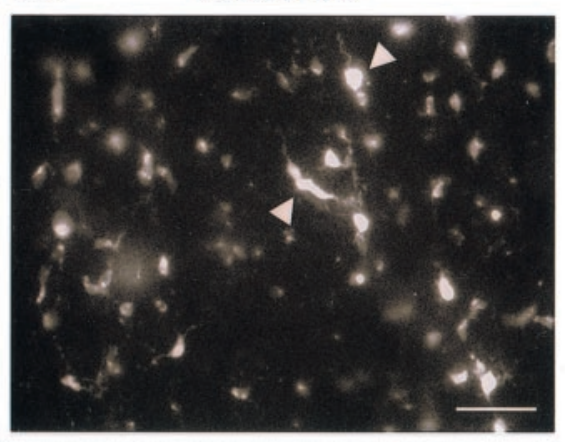

D

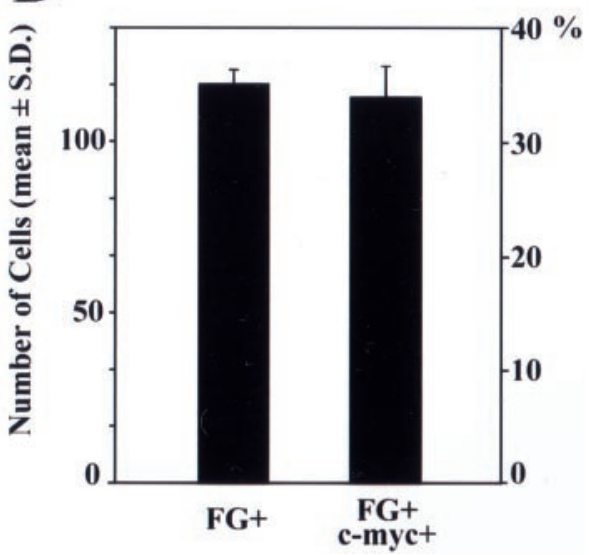
BDNF and enhances neuronal survival.

We next examined the stimulation of known downstream components of the TrkB signaling cascade, the MAP kinases extracellular signal-related kinase (Erk) $1 / 2$ and Akt, using antibodies that specifically recognized the phosphorylated forms of these kinases. Of interest, low but detectable levels of Erk1/2 and Akt phosphorylation were observed in intact uninjected retinas, indicating basal activation of these kinases (Fig. $5 B, C$ ). In contrast, intraocular injection of AAV.TrkB, in the absence of exogenous BDNF, resulted in marked activation of both Erk1 and Erk2 compared with the low levels of phosphorylation observed in 


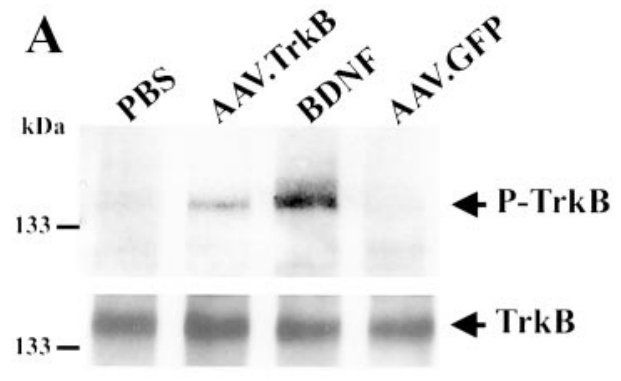

P-TrkB $\left[\begin{array}{l}\text { IP:anti-panTrk } \\ \text { Probe: Anti-phosphotyrosine }\end{array}\right.$
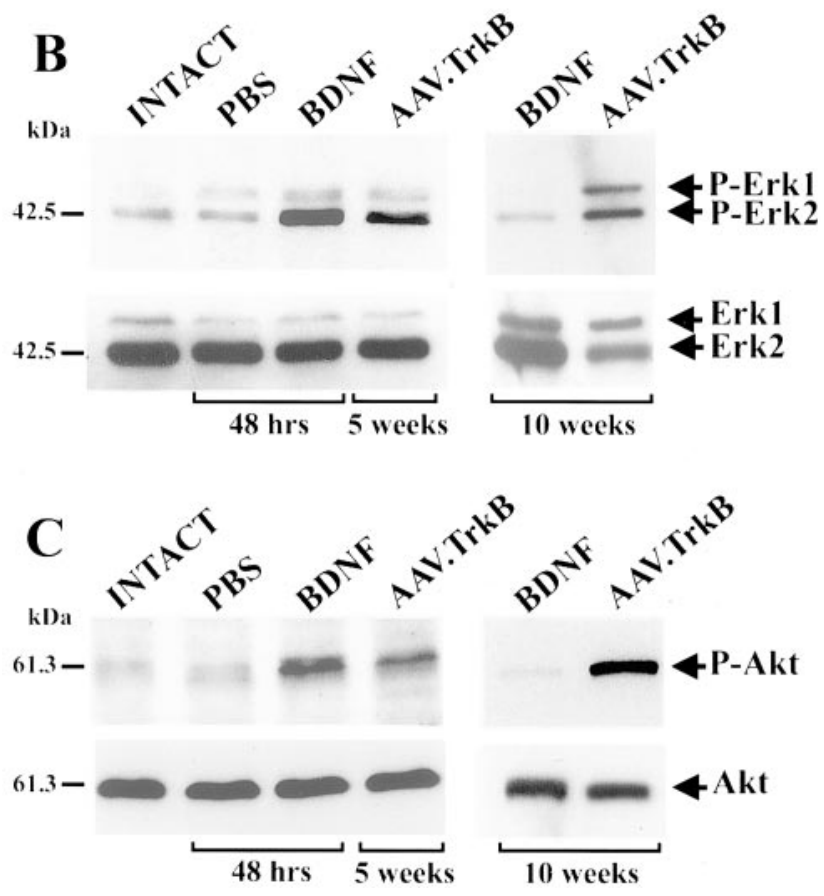

Figure 5. In vivo activation of retinal components of the BDNF/TrkB signaling pathway after TrkB gene transfer to RGCs. $A$, Tyrosine phosphorylation of retinal TrkB at 5 weeks after a single intraocular injection of AAV.TrkB was examined by immunoprecipitation of $\sim 300 \mu \mathrm{g}$ of retinal protein with an anti-pan Trk (203) antibody followed by Western blot analysis using anti-phosphotyrosine (4G10) antibody. Controls included anti-pan Trk immunoprecipitated samples from retinas at 5 weeks after AAV.GFP injection and at $48 \mathrm{hr}$ after BDNF or PBS injection. The bottom panel shows the same blot probed with an antibody that recognizes the intracellular domain of TrkB $\left(\operatorname{TrkB}_{\text {in }}\right) . B$, Activation of the MAP kinases Erk1 and Erk2 was investigated using Western blots of total retinal extracts $(75-100 \mu \mathrm{g})$ probed with an antibody that selectively recognizes both Erk1 and Erk2 phosphorylated on Thr202/Tyr204 residues. Stimulation of Erk1/2 was detected at 5 and 10 weeks after intravitreal injection of AAV.TrkB. Controls include retinal samples collected at $48 \mathrm{hr}$ or 10 weeks after injection of BDNF protein. The bottom panel shows the same blot reprobed with a p44/42 MAP kinase antibody to visualize total Erk protein. $C$, Akt activation at 5 and 10 weeks after TrkB gene transfer was detected using a phospho-Akt-specific antibody that recognizes Akt phosphorylated on Thr308. Controls are similar as for $B$. The bottom panel shows the same blot reprobed with an anti-Akt antibody that allows visualization of total Akt protein.

control retinas injected with PBS (Fig. 5B) or AAV.GFP (data not shown). Similarly, a marked increase in Akt phosphorylation was observed after injection of AAV.TrkB (Fig. 5C). These results clearly demonstrate stimulation of both the MAPK and the Akt pathways in RGCs after AAV-mediated TrkB gene transfer. As
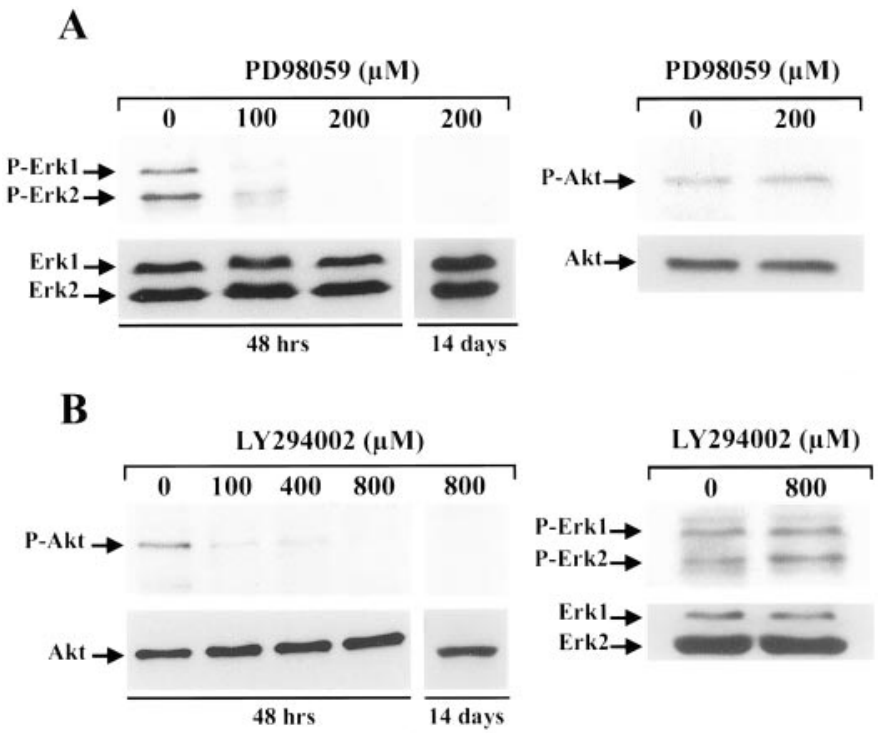

Figure 6. Selective inhibition of AAV.TrkB-induced activation of retinal MAPK and Akt. $A$, Western blots of whole retinal homogenates show dose-dependent blockade of AAV.TrkB-induced activation of Erk1/2 with PD98059, a selective inhibitor of MEK. Inhibition of Erk1/2 phosphorylation was observed at $48 \mathrm{hr}$ and $14 \mathrm{~d}$ after intraocular injection of $200 \mu \mathrm{M}$ PD98059. The intravitreal concentration of this compound was $\sim 16.7 \mu \mathrm{M}$ based on the estimated volume of the vitreous chamber in the adult rat eye $(\sim 60 \mu \mathrm{l})$. Phosphorylated Erk1 and Erk2 were visualized with an antibody against phospho-MAPK (Thr202/Tyr204 residues) (top panel), and total Erk protein was visualized in the same blot reprobed with p44/42 MAP kinase antibody (bottom panel). Intraocular injection of 200 $\mu \mathrm{M}$ PD98059, which effectively inhibited Erk1/2 activation, did not block Akt phosphorylation (right panels). This result confirms the biochemical specificity of the pharmacological inhibitor PD98059. B. Akt phosphorylation induced by TrkB gene transfer was blocked at $48 \mathrm{hr}$ and $14 \mathrm{~d}$ after single intravitreal injection of $800 \mu \mathrm{M}$ LY294002 (intravitreal concentration $\sim 66.7 \mu \mathrm{M}$ ), a selective inhibitor of PI-3K. Activated Akt was visualized with an antibody against phospho-Akt (Thr308; top panel); total Akt protein was visualized in the same blot reprobed with an anti-Akt antibody (bottom panel). Administration of $800 \mu \mathrm{M}$ LY294002, which inhibited Akt stimulation, did not block Erk1/2 phosphorylation, confirming the specificity of LY294002 (right panels).

in the case of TrkB phosphorylation, AAV.TrkB-induced activation of Erk1/2 and Akt was detected at 5 and 10 weeks after intraocular administration of the viral vector (Fig. 5B,C).

\section{TrkB-induced survival of axotomized RGCs in vivo occurs via a MAPK-dependent pathway}

To determine whether MAPK and Akt signaling were involved in TrkB-mediated survival of axotomized RGCs, pharmacological inhibitors of specific components of each of these pathways were used. PD98059 selectively inhibits MEK (Dudley et al., 1995), the upstream activator of MAPK, and LY294002 is a selective inhibitor of PI-3K (Weber et al., 1997), an upstream Akt activator. First, we determined the concentration of these compounds required to effectively block AAV.TrkB-induced activation of retinal Erk1/2 and Akt in vivo. For this purpose, eyes were injected with AAV.TrkB, and 4 weeks later the inhibitor PD98059 or LY294002 was delivered by a single injection into the vitreous chamber. Inhibition of Erk1/2 or Akt phosphorylation was analyzed by Western blots of whole retinal homogenates collected at $48 \mathrm{hr}$ or $14 \mathrm{~d}$ after administration of each compound (Fig. 6). The inhibitory effect of PD98059 or LY294002 in vivo was dose dependent. Intravitreal injection of $200 \mu \mathrm{M}$ PD98059 effectively blocked Erk1/2 phosphorylation (Fig. $6 A$ ), and injection of 800 


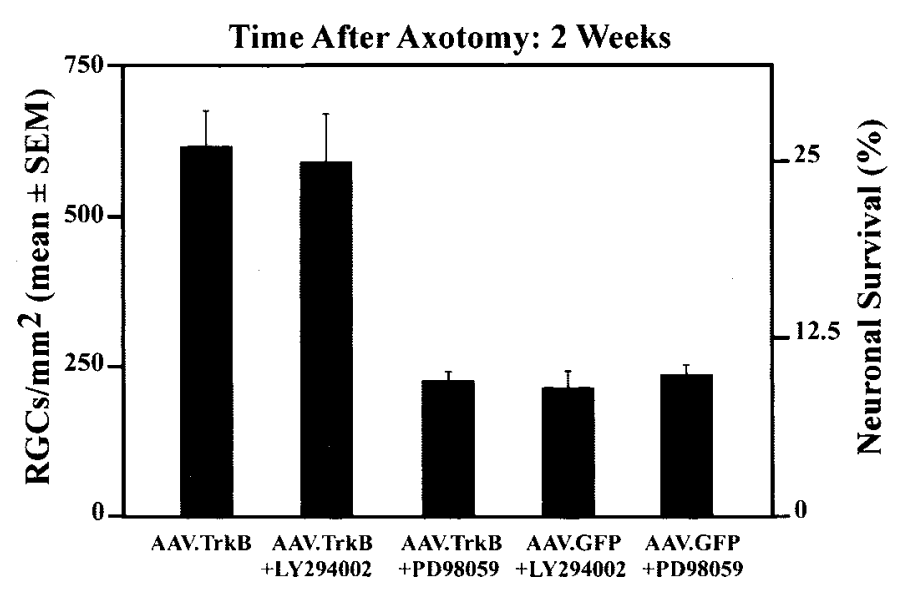

Figure 7. TrkB uses MAPK activation to promote the survival of adult RGCs in vivo. A, Effect of the pharmacological inhibitors PD98059 and LY294002 on AAV.TrkB-induced RGC survival. The density of RGCs that survived after TrkB gene transfer with AAV.TrkB was significantly reduced by specific inhibition of the MEK/MAPK pathway with a single intraocular injection of PD98059 $(200 \mu \mathrm{M})$ at the time of axotomy $(p<$ $0.001 ; t$ test). In contrast, AAV.TrkB-induced neuronal survival was not significantly changed by injection of LY294002 $(800 \mu \mathrm{M})$, a specific inhibitor of PI-3K ( $p=0.798$; $t$ test $)$.

$\mu \mathrm{M}$ LY294002 inhibited Akt phosphorylation (Fig. 6B). Because the volume of the vitreous chamber in the adult rat eye is $\sim 60 \mu \mathrm{l}$, the final intravitreal concentration of these drugs was $\sim 16.7 \mu \mathrm{M}$ for PD98059 and $\sim 66.7 \mu \mathrm{M}$ for LY294002, well within the range shown to work effectively in vitro (Atwal et al., 2000). Of interest, effective inhibition of AAV.TrkB-induced retinal MAPK and Akt activation was sustained for at least $14 \mathrm{~d}$ after administration of these drugs (Fig. 6A,B). There was no reduction in the phosphorylation of Erk1/2 in the presence of LY294002 (Fig. 6B). Similarly, phosphorylation of Akt was not decreased with PD98059 (Fig. 6A). These results confirmed the specificity of the inhibitory effect of each of these compounds in vivo. Examination of histological sections and whole mounts of the treated retinas found no inherent toxic or pro-survival effect of these chemicals.

We then performed in vivo RGC survival assays after AAV.TrkB delivery in the presence of PD98059 or LY294002 injected intravitreally at the time of optic nerve transection (Fig. 7, Table 1). Administration of PD98059 (200 $\mu \mathrm{M})$ resulted in complete inhibition of the survival effect produced by TrkB gene transfer. In this situation, RGC density was low and similar to that found in retinas treated with the control virus AAV.GFP. In contrast, blockade of PI-3K activation with LY294002 (800 $\mu \mathrm{M})$ did not change the neuroprotective effect induced by AAV.TrkB. These results demonstrate that although the MEK/MAPK pathway is essential for TrkB-mediated survival of injured adult RGCs in vivo, the PI-3K/Akt pathway has no apparent role in this survival effect.

\section{DISCUSSION}

Injury-induced changes in the expression of critical components of survival pathways may exacerbate the death of CNS neurons. Here we demonstrate that expression of TrkB, a key player in BDNF-induced survival, is downregulated in adult RGCs after axotomy close to the eye. The striking reduction in TrkB mRNA within 2 weeks of axotomy correlated with the inability of RGCs to survive in response to BDNF, despite sustained neurotrophin delivery (Di Polo et al., 1998). Downregulation of neuronal Trk receptors has been reported in the damaged rat spinal cord (Kobayashi et al., 1997; Liebl et al., 2001) and brain (Venero et al., 1994), suggesting that this is a common response to acute injury among some CNS neurons. In contrast to TrkB, BDNF mRNA levels have been shown to increase transiently in cells of the ganglion cell layer after optic nerve crush (Gao et al., 1997), but there is no evidence that this local upregulation delays the onset of RGC death. Taken together, these results suggest that reduced TrkB expression in injured RGCs contributes to their desensitization to exogenous, and possibly endogenous, BDNF.

This hypothesis was tested by increasing the capacity of axotomized RGCs to respond to BDNF after TrkB gene delivery. A key issue in the success of these experiments was the identification of a vector system for efficient infection of adult RGCs in vivo. Previous studies showed that intravitreal injection of AAV resulted in transduction of cells in the ganglion cell layer (Grant et al., 1997; Ali et al., 1998; Dudus et al., 1999), but given that both RGCs and amacrine neurons populate this retinal layer, the specific cellular tropism of this virus was not established. Our data indicate that RGCs are the main target for AAV infection in the inner retina. Furthermore, we show that an average of $68 \%$ of the total RGC population was effectively infected by AAV, and in some individual retinas up to $75 \%$ of RGCs were transduced. Interestingly, heparan sulfate proteoglycan, the primary receptor responsible for AAV attachment to the host cell (Summerford and Samulski, 1998), is expressed on adult RGCs (A. Di Polo, unpublished observations), providing a likely mechanism behind the tropism of this virus in the inner retina.

Two main findings support our conclusion that AAV.TrkB promotes the survival of RGCs by augmenting their capacity to respond to BDNF. First, the neuroprotective effect of AAV.TrkB dramatically increased when it was combined with a single intraocular injection of BDNF. This survival effect was apparent at all times examined but was particularly striking at 2 and 3 weeks after axotomy. For example, an average of $76 \%$ of RGCs remained alive at 2 weeks after axotomy, a time when typically $<10 \%$ of these neurons survive in the absence of treatment. Although the total number of neurons in all experimental groups was lower at 3 weeks after injury, the combined effect of AAV.TrkB and BDNF yielded an approximately sixfold higher number of surviving neurons than AAV.TrkB alone. Furthermore, AAV.TrkB and BDNF administration effectively extended RGC survival by at least $10 \mathrm{~d}$, a substantial amount of time compared with the shorter effect of BDNF protein alone (Mansour-Robaey et al., 1994; Peinado-Ramon et al., 1996; Clarke et al., 1998) or BDNF gene transfer (Di Polo et al., 1998), which delayed RGC death by only $2 \mathrm{~d}$. To our knowledge, this level and extent of survival have not been achieved previously in a model of acute RGC death.

Second, we found a tight correlation between expression of AAV-mediated TrkB and neuronal survival. At 3 weeks after axotomy, $\sim 96 \%$ of the surviving RGCs expressed c-myc-tagged TrkB, suggesting that upregulation of this receptor increased the capacity of these neurons to respond to BDNF. Interestingly, studies using highly purified postnatal day 8 RGC cultures have shown that TrkB internalization is likely to contribute to the loss of trophic responsiveness after axotomy (Meyer-Franke et al., 1998; Shen et al., 1999). Although we cannot rule out the possibility that TrkB internalization restricts RGC survival in this model, our results suggest that within the first weeks of injury a sufficient quantity of virally delivered TrkB is available to elicit 
cell survival after trophic stimulation, perhaps overwhelming any internalization process.

Our data demonstrate that although both MAPK and Akt pathways were activated after TrkB gene transfer, only selective inhibition of MEK blocked AAV.TrkB-induced survival, whereas PI-3K inhibition had no effect. This finding strongly suggests that the MEK/MAPK pathway, but not the PI-3K/Akt pathway, is necessary for AAV.TrkB-induced survival of axotomized RGCs. MEK inhibition has also been shown to block the ability of early postnatal RGCs to survive after axonal injury (Shen et al., 1999). Therefore, the MEK/MAPK pathway appears to be a common survival signaling mechanism used by both developing and adult axotomized RGCs in response to TrkB stimulation. MEK/ MAPK activity may regulate the survival of RGCs by activating the transcriptional factor CAMP response element-binding protein (CREB), which is known to mediate BDNF-induced survival of cultured cerebellar neurons (Bonni et al., 1999). Of interest, CREB phosphorylation in RGCs has been observed after BDNF stimulation in mouse retinal organ cultures (Wahlin et al., 2000).

It is now well established that Trk activation leads to the stimulation of multiple signaling pathways in the same neuron (Segal and Greenberg, 1996; Kaplan and Miller, 1997; Klesse et al., 1999). Recent in vitro studies in NGF-dependent neonatal sympathetic neurons have indicated that although TrkA uses PI-3K to stimulate cell survival, TrkB uses both PI-3K and MEK (Atwal et al., 2000). There is growing evidence, however, indicating that the specific role of each of these pathways on Trkinduced survival appears to be tightly dependent on neuronal type and injury modality. Although the PI-3K pathway is critical in growth factor-mediated survival during trophic deprivation in various PNS and CNS neurons in vitro (Kaplan and Miller, 2000), the MAPK pathway has been implicated in the survival induced by neurotrophins after physical or chemical injury. MAPK signaling is also responsible for the in vitro protection of cerebellar granule neurons from oxidative stress (Skaper et al., 1998), cortical neurons from camptothecin-induced apoptosis (Hetman et al., 1999), and sympathetic neurons from cytosine arabinoside toxicity (Anderson and Tolkovsky, 1999). In vivo, the MAPK pathway has been shown to protect the neonatal brain from hypoxic-ischemic injury (Hee Han and Holtzman, 2000). What then is the role of PI-3K/AKT activation in adult RGCs after TrkB stimulation? Although not apparently involved in BDNF/ TrkB-induced survival, this pathway may mediate other, as yet undefined, functions closely related to the RGC response to trophic stimulation, such as axonal regrowth. Interestingly, the PI-3K pathway has been implicated in RGC protection by insulin growth factor and tumor necrosis factor $\alpha$ (Kermer et al., 2000; Diem et al., 2001), suggesting that different neurotrophic factors promote the survival of adult RGCs by distinct intracellular signaling mechanisms.

In summary, our findings indicate that downregulation of TrkB after RGC injury is a key mechanism underlying the short-lived survival effect produced by exogenous BDNF. We report a novel neuroprotective strategy based on TrkB gene delivery in vivo that significantly enhances the survival of RGCs after axotomy. This strategy may have therapeutic potential in the injured CNS; however, future studies are required to resolve important issues such as the efficacy of this approach in models of protracted neuronal death and to evaluate the functional state of the rescued neurons.

\section{REFERENCES}

Aguayo AJ, Clarke DB, Jelsma TN, Kittlérova P, Friedman HC, Bray GM (1996) Effects of neurotrophins on the survival and regrowth of injured retinal neurons. Ciba Found Symp 196:135-144.

Ali RR, Reichel MB, De Alwis M, Kanuga N, Kinnon C, Levinsky RJ, Hunt DM, Bhattacharya SS, Thrasher AJ (1998) Adeno-associated virus gene transfer to mouse retina. Hum Gene Ther 9:81-86.

Anderson CNG, Tolkovsky AM (1999) A role for MAPK/ERK in sympathetic neuron survival: protection against a p53-dependent, JNKindependent induction of apoptosis by cytosine arabinoside. J Neurosci 19:664-673.

Atwal JK, Massie B, Miller FD, Kaplan DR (2000) The TrkB-Shc site signals neuronal survival and local axon growth via MEK and PI3kinase. Neuron 27:265-277.

Bartlett SE, Reynolds AJ, Weible M, Heydon K, Hendry IA (1997) In sympathetic but not sensory neurons, phosphoinositide-3 kinase is important for NGF-dependent survival and retrograde transport of 125I- $\beta$ NGF. Brain Res 76:257-262.

Berkelaar M, Clarke DB, Wang Y-C, Bray GM, Aguayo AJ (1994) Axotomy results in delayed death and apoptosis of retinal ganglion cells in adult rats. J Neurosci 14:4368-4374.

Bonni A, Brunet A, West AE, Datta SR, Takasu MA, Greenberg MA (1999) Cell survival promoted by the Ras-MAPK signaling pathway by transcription-dependent and -independent mechanisms. Science 286:1358-1362.

Cellerino A, Kohler K (1997) Brain-derived neurotrophic factor/ neurotrophin-4 receptor Trkb is localized on ganglion cells and dopaminergic amacrine cells in the vertebrate retina. J Comp Neurol 386:149-160.

Chen H, Weber AJ (2001) BDNF enhances retinal ganglion cell survival in cats with optic nerve damage. Invest Ophthalmol Vis Sci 42:966-974

Clarke DB, Bray GM, Aguayo AJ (1998) Prolonged administration of NT-4/5 fails to rescue most axotomized retinal ganglion cells in adult rats. Vision Res 38:1517-1524.

Crowder RJ, Freeman RS (1998) Phosphatidylinositol 3-kinase and Akt protein kinase are necessary and sufficient for the survival of nerve growth factor-dependent sympathetic neurons. J Neurosci 18:2933-2943.

Dangerlind A, Friberg K, Bean AJ, Hokfelt T (1992) Sensitive mRNA detection using unfixed tissue: combined radioactive and nonradioactive in situ hybridization histochemistry. Histochemistry 98:39-49.

Diem R, Meyer R, Weishaupt JH, Bähr M (2001) Reduction of potassium currents and phosphatidylinositol 3-kinase-dependent Akt phosphorylation by tumor necrosis factor- $\alpha$ rescues axotomized retinal ganglion cells from retrograde cell death in vivo. J Neurosci 21:2058-2066.

Di Polo A, Aigner LJ, Dunn RJ, Bray GM, Aguayo AJ (1998) Prolonged delivery of brain-derived neurotrophic factor by adenovirusinfected Müller cells temporarily rescues injured retinal ganglion cells. Proc Natl Acad Sci USA 95:3978-3983.

Dolcet X, Egea J, Soler RM, Martin-Zanca D, Comella JX (1999) Activation of phosphatidylinositol 3-kinase, but not extracellularregulated kinases, is necessary to mediate brain-derived neurotrophic factor-induced motoneuron survival. J Neurochem 73:521-531.

Dudek H, Datta SD, Franke TF, Birnbaum MJ, Yao R, Cooper GM, Segal RA, Kaplan DK, Greenberg ME (1997) Regulation of neurona survival by the serine-threonine kinase Akt. Science 275:661-665.

Dudley DT, Pang L, Decker SJ, Bridges AJ, Saltiel AR (1995) A synthetic inhibitor of the mitogen-activated protein kinase cascade. Proc Natl Acad Sci USA 92:7686-7689.

Dudus L, Anand V, Acland GM, Chen S-J, Wilson JM, Fisher KJ, Maguire AM, Bennett J (1999) Persistent transgene product in retina, optic nerve and brain after intraocular injection of rAAV. Vision Res 39:2545-2553.

Ferrari FK, Samulski T, Shenk T, Samulski RJ (1996) Second-strand synthesis is a rate-limiting step for efficient transduction by recombinant adeno-associated virus vectors. J Virol 70:3227-3234.

Gao H, Qiao X, Hefti F, Hollyfield JG, Knüsel B (1997) Elevated mRNA expression of brain-derived neurotrophic factor in retinal ganglion cell layer after optic nerve injury. Invest Ophthalmol Vis Sci 38:1840-1847.

Grant CA, Selvarangan P, Wang X-S, Srivastava A, Li T (1997) Evaluation of recombinant adeno-associated virus as a gene transfer vector for the retina. Curr Eye Res 16:949-956.

Grimm D, Kern A, Rittner K, Kleinschmidt JA (1998) Novel tools for production and purification of recombinant adeno-associated virus vectors. Hum Gene Ther 9:2745-2760.

Guy J, Qi X, Muzyczka N, Hauswirth WW (1999) Reporter expression persists 1 year after adeno-associated virus-mediated gene transfer to the optic nerve. Arch Ophthalmol 117:929-937.

Hauswirth WW, Lewin AS, Zolotukhin S, Muzyczka N (2000) Production and purification of recombinant adeno-associated virus. Methods Enzymol 316:743-761. 
Hee Han B, Holtzman M (2000) BDNF protects the neonatal brain from hypoxic-ischemic injury in vivo via the ERK pathway. J Neurosci 20:5775-5781.

Hetman M, Kanning K, Cavanaugh JE, Xia Z (1999) Neuroprotection by brain-derived neurotrophic factor is mediated by extracellular signal-regulated kinase and phosphatidylinositol 3-kinase. J Biol Chem 274:22569-22580.

Huang EJ, Reichardt LF (2001) Neurotrophins: roles in neuronal development and function. Annu Rev Neurosci 24:677-736.

Jelsma TN, Hyman Friedman H, Berkelaar M, Bray GM, Aguayo AJ (1993) Different forms of the neurotrophin receptor trkB mRNA predominate in rat retina and optic nerve. J Neurobiol 24:1207-1214.

Kaplan DR, Miller FD (1997) Signal transduction by the neurotrophin receptors. Curr Opin Cell Biol 9:213-221.

Kaplan DR, Miller FD (2000) Neurotrophin signal transduction in the nervous system. Curr Opin Neurobiol 10:381-391.

Kermer P, Klöcker N, Labes M, Bähr M (2000) Insulin-like growth factor-1 protects axotomized rat retinal ganglion cells from secondary death via PI3-K-dependent Akt phosphorylation and inhibition of caspase-3 in vivo. J Neurosci 20:722-728.

Klesse LJ, Parada LF (1999) Trks: signal transduction and intracellular pathways. Microsc Res Tech 45:210-216.

Klesse LJ, Meyers KA, Marshall CJ, Parada LF (1999) Nerve growth factor induces survival and differentiation through two distinct signaling cascades in PC12 cells. Oncogene 18:2055-2068.

Klöcker N, Cellerino A, Bähr M (1998) Free radical scavenging and inhibition of nitric oxide synthase potentiates the neurotrophic effect of brain-derived neurotrophic factor on axotomized retinal ganglion cells in vivo. J Neurosci 18:1038-1046.

Kobayashi NR, Fan D-P, Giehl KM, Bedard AM, Wiegand SJ, Tetzlaff W (1997) BDNF and NT-4/5 prevent atrophy of rat rubrospinal neurons after cervical axotomy, stimulate GAP-42 and T $\alpha 1$-tubulin mRNA expression, and promote axonal regeneration. J Neurosci 17:9583-9595.

Leon S, Yin Y, Nguyen J, Irwin N, Benowitz LI (2000) Lens injury stimulates axon regeneration in the mature rat optic nerve. J Neurosci 20:4615-4626.

Lewin GR, Barde YA (1996) Physiology of the neurotrophins. Annu Rev Neurosci 19:289-317.

Liebl DJ, Huang W, Young W, Parada LF (2001) Regulation of Trk receptors following contusion of the rat spinal cord. Exp Neurol 167:15-26.

Malik AK, Monahan PE, Allen DL, Chen B-G, Samulski RJ, Kurachi K (2000) Kinetics of recombinant adeno-associated virus-mediated gene transfer. J Virol 74:3555-3565.

Mansour-Robaey S, Clarke DB, Wang Y-C, Bray GM, Aguayo AJ (1994) Effects of ocular injury and administration of brain-derived neurotrophic factor on survival and regrowth of axotomized retinal ganglion cells. Proc Natl Acad Sci USA 91:1632-1636.

McKerracher L, Essagian C, Aguayo AJ (1993) Marked increase in $\beta$-tubulin mRNA expression during regeneration of axotomized retinal ganglion cells in adult mammals. J Neurosci 13:5294-5300.

Mey J, Thanos S (1993) Intravitreal injections of neurotrophic factors support the survival of axotomized retinal ganglion cells in adult rats in vivo. Brain Res 602:304-317.

Meyer-Franke A, Wilkinson A, Kruttgen A, Hu M, Munro E, Hanson MG, Reichardt LF, Barres BA (1998) Depolarization and cAMP elevation rapidly recruit TrkB to the plasma membrane of CNS neurons. Neuron 21:681-693.

Olfert ED, Cross BM, McWilliams A (1993) The guide to the care and use of experimental animals. Ottawa: Canadian Council on Animal Care.
Orike N, Middleton G, Borthwick E, Buchman V, Cowen T, Davies AM (2001) Role of PI 3-kinase, Akt and Bcl-2-related proteins in sustaining the survival of neurotrophic factor-independent adult sympathetic neurons. J Cell Biol 154:995-1005.

Peinado-Ramon P, Salvador M, Villegas-Perez MP, Vidal-Sanz M (1996) Effects of axotomy and intraocular administration of NT-4, NT-3 and brain-derived neurotrophic factor on the survival of adult rat retinal ganglion cells. A quantitative in vivo study. Invest Ophthalmol Vis Sci $37: 489-500$

Pérez MTR, Caminos E (1995) Expression of brain-derived neurotrophic factor and its functional receptor in neonatal and adult rat retina. Neurosci Lett 183:96-99.

Perry VH (1981) Evidence for an amacrine cell system in the ganglion cell layer of the rat retina. Neuroscience 6:931-944.

Rickman DW, Brecha NC (1995) Expression of the proto-oncogene, trk, receptors in the developing rat retina. Vis Neurosci 12:215-222.

Segal R, Greenberg ME (1996) Intracellular signaling pathway activated by neurotrophic factors. Annu Rev Neurosci 19:463-489.

Shen S, Wiemelt AP, McMorris FA, Barres BA (1999) Retinal ganglion cells lose trophic responsiveness after axotomy. Neuron 23:285-295.

Skaper SD, Floreani M, Negro A, Facci L, Giusti P (1998) Neurotrophins rescue cerebellar granule neurons from oxidative stress-mediated apoptotic death: selective involvement of phosphatidylinositol 3-kinase and the mitogen-activated protein kinase pathway. J Neurochem 70:1859-1868.

Sofroniew MV, Howe CL, Mobley WC (2001) Nerve growth factor signaling, neuroprotection and neural repair. Annu Rev Neurosc 24:1217-1281.

Stephens RM, Loeb DM, Copeland TD, Pawson T, Greene LA, Kaplan DR (1994) Trk receptors use redundant signal transduction pathways involving SHC and PLC- $\gamma 1$ to mediate NGF responses. Neuron 12:691-705.

Summerford C, Samulski RJ (1998) Membrane-associated heparan sulfate proteoglycan is a receptor for adeno-associated virus type 2 virions. J Virol 72:1428-1445.

Venero JL, Knüsel B, Beck KD, Hefti F (1994) Expression of neurotrophins and trk receptor genes in adult rats with fimbria transection: effect of intraventricular nerve growth factor and brain-derived neurotrophic factor administration. Neuroscience 59:797-815.

Villegas-Perez MP, Vidal-Sanz M, Rasminsky M, Bray GM, Aguayo AJ (1993) Rapid and protracted phases of retinal ganglion cell loss follow axotomy in the optic nerve of adult rats. J Neurobiol 24:23-36.

Wahlin KJ, Campochiaro PA, Zack DJ, Adler R (2000) Neurotrophic factors cause activation of intracellular signaling pathways in Müller cells and other cells of the inner retina, but not photoreceptors. Invest Ophthalmol Vis Sci 41:927-936.

Weber G, Shen F, Prajda N, Yang H, Li W, Yeh A, Csokay B, Olah E, Look KY (1997) Regulation of the signal transduction program by drugs. Adv Enzyme Regul 37:35-55.

Xia Z, Dickens M, Raingeaud J, Davis RJ, Greenberg ME (1995) Opposing effects of ERK and JNK-p38 MAP kinases on apoptosis. Science 270:1326-1331.

Xiao X, Li J, Samulski RJ (1996) Long-term and efficient in vivo gene transfer into muscle tissue of immunocompetent mice with an rAAV vector. J Virol 70:8098-8108.

Xiao X, Li J, McCown TJ, Samulski RJ (1997) Gene transfer by adenoassociated virus vectors into the central nervous system. Exp Neurol 144:113-124.

Zolotukhin S, Potter M, Hauswirth WW, Guy J, Muzyczka N (1996) A "humanized" green fluorescent protein cDNA adapted for high-level expression in mammalian cells. J Virol 70:4646-4654. 